\title{
Which appendicitis scoring system is most suitable for pregnant patients? A comparison of nine different systems
}

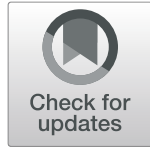

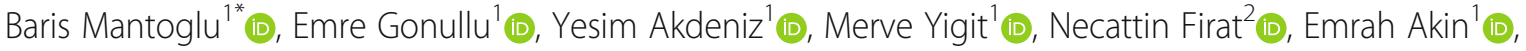 \\ Fatih Altintoprak ${ }^{2}$ (D) and Unal Erkorkmaz ${ }^{3}$ (D)
}

\begin{abstract}
Background: Acute appendicitis is the most common non-gynecological emergency during pregnancy. The diagnosis of appendicitis during pregnancy is challenging due to changes in both physiological and laboratory variables. Guidelines suggest patients with suspected acute appendicitis should be stratified based on clinical scoring systems, to optimize the use of diagnostic imaging and prevent unnecessary surgery. Surgeons require additional information beyond that provided by imaging studies before deciding upon exploratory laparoscopy in patients with a high suspicion of appendicitis. Various scoring methods have been evaluated for the diagnosis of acute appendicitis. However, there is no consensus on a method to use during pregnancy, and a detailed comparison of existing scoring methods for this purpose has not yet been conducted. The purpose of this study was to evaluate the efficacy of the most popular scoring systems applied to diagnose acute appendicitis during pregnancy.
\end{abstract}

Methods: This single-center retrospective study included 79 pregnant patients who were admitted to the emergency department with abdominal pain between May 2014 and May 2019. The patients were diagnosed with acute appendicitis and underwent an appendectomy. As a control group, the study also included 79 non-pregnant patients who underwent appendectomy within the last 1.5 years. To ensure that the groups were similar, women in the case group were stratified according to age, and the proportions of women in the strata were determined. The women in the control group were similarly stratified. Women were randomly selected from the strata to prevent bias. Both laboratory and examination findings required for each scoring method were obtained and assessed separately for each patient. Negative appendectomy rates were evaluated according to pathology results. Categorical variables were compared using the chi-square test. A $p$ value $<0.05$ was considered to indicate significance. Receiver operator characteristic curve analysis was used to identify the best threshold value and to assess the performance of the test scores in terms of diagnosing appendicitis.

Results: Among all scoring systems, the Tzanakis score was most efficacious at predicting appendicitis in non-pregnant women. The positive predictive value (PPV) of the Tzanakis score was 90.6\%, whereas the negative predictive value (NPV) was 46.7\%. The RIPASA score performed the best among the scoring systems in pregnant women. It was associated with a PPV of 94.40\%, NPV of $44 \%$, and sensitivity and specificity of $78.46 \%$ and $78.57 \%$, respectively.

(Continued on next page)

\footnotetext{
* Correspondence: barismantoglu@gmail.com.tr

'Department of General Surgery, Sakarya University Educating and Research

Hospital, Sakarya, Turkey

Full list of author information is available at the end of the article
}

(c) The Author(s). 2020 Open Access This article is licensed under a Creative Commons Attribution 4.0 International License, which permits use, sharing, adaptation, distribution and reproduction in any medium or format, as long as you give appropriate credit to the original author(s) and the source, provide a link to the Creative Commons licence, and indicate if changes were made. The images or other third party material in this article are included in the article's Creative Commons licence, unless indicated otherwise in a credit line to the material. If material is not included in the article's Creative Commons licence and your intended use is not permitted by statutory regulation or exceeds the permitted use, you will need to obtain permission directly from the copyright holder. To view a copy of this licence, visit http://creativecommons.org/licenses/by/4.0/ The Creative Commons Public Domain Dedication waiver (http://creativecommons.org/publicdomain/zero/1.0/) applies to the data made available in this article, unless otherwise stated in a credit line to the data. 
(Continued from previous page)

Conclusion: Although the RIPASA score can be used to efficaciously diagnose acute appendicitis in pregnant women, a specific scoring system is needed for diagnosis during the gestation period.

Keywords: Appendicitis, Pregnancy, Score, Predictive value

\section{Background}

Acute appendicitis is the most common cause of nonobstetric emergency surgery in pregnant women. Appendicitis occurs in one out of 1500 pregnant women [1]. Furthermore, negative appendectomy rates in females of reproductive age are reported to be up to $26 \%$ [2]. The differential diagnosis of acute abdominal pain during pregnancy is more complicated than in typical patients. In addition to symptoms such as nausea, vomiting, and abdominal pain, which are common during pregnancy, an increased white blood cell (WBC) count and limited radiological methods complicate the diagnosis of acute appendicitis [3-5]. Unfortunately, negative appendectomy rates remain relatively high regardless of the testing conducted [6-10].

The main goals in the diagnosis of appendicitis are to reduce negative appendectomy rates, avoid perforation, and protect the patient from unnecessary surgical intervention. A meta-analysis reported that it is essential to make an exact diagnosis and avoid any delay therein [11]. However, another article reported that a delay in the diagnosis of uncomplicated appendicitis of up to $24 \mathrm{~h}$ is safe [12]. That article stated that non-operative management through antibiotic treatment is safe in cases of uncomplicated appendicitis. Unfortunately, the rates of abortion and preterm labor are significantly higher in women with appendicitis $[13,14]$. Timely diagnosis is critical, as delays may lead to both maternal (1-4\%) and fetal (1.5-35\%) mortality due to perforation of the appendix [15]. To this end, various scoring methods have been developed based on imaging studies, clinical findings, and laboratory results [16-24]. The present study aimed to evaluate the extent to which these scoring methods are suitable for the diagnosis of appendicitis in pregnancy.

\section{Methods}

This study included 79 pregnant patients who were admitted to the Sakarya University Faculty of Medicine (Serdivan, Turkey) with abdominal pain between May 2014 and May 2019. The patients were diagnosed with acute appendicitis and underwent appendectomy. The study also included a control group of 79 non-pregnant patients who underwent appendectomy within the last 1.5 years. To ensure similar groups, women in the case group were stratified according to age, and the proportions of women in the strata were determined. The women in the control group were similarly stratified.
Women were randomly selected from the strata to avoid possible bias. Patients under the age of 20 or older than 45 were excluded from the control group, as well as those with chronic co-morbidities (e.g., hypertension, diabetes mellitus, chronic renal failure, or chronic pulmonary disease). All pregnant patients were examined by the obstetrician both before and after surgery.

Nine appendicitis clinical score methods were used for evaluating the patients. These clinical scoring systems (CSS) included the Alvarado, Eskelinen, Ohmann, AIR, RIPASA, Tzanakis, Lintula, Fenyo-Lindberg, and Karaman systems. Laboratory data such as WBC count, neutrophil count, and C-reactive protein level were collected, as well as examination findings and symptoms. In an Excel file, formulas were prepared separately for each CSS, and the data obtained from each patient were entered into the file so that CSS scores were calculated automatically. A visual analog scale pain score was calculated for all patients hospitalized with a diagnosis of acute appendicitis, who were classified into mild, moderate, and severe pain subgroups according to the literature [25]. This helped with calculating the score for the Lintula system, in which the pain system was graded at three different levels. Negative appendectomy rates were evaluated according to pathology results. The ethics committee of our university approved the study.

\section{Statistical analysis}

Descriptive analyses were performed to provide information on the general characteristics of the study population. The Kolmogorov-Smirnov test was used to evaluate whether the distributions of numeric variables were normal. Accordingly, either independent sample $t$ tests or Mann-Whitney $U$ tests were used to compare the numeric variables between pregnant and non-pregnant patients. The numeric variables are presented as the mean \pm standard deviation or medians with interquartile ranges in square brackets. Categorical variables were compared using chi-square tests. Categorical variables are presented as counts and percentages. A $p$ value $<0.05$ was considered to indicate significance. Receiver operating characteristic curve analysis was used to identify the optimal threshold values and assess the diagnostic performance of test scores for appendicitis. Analyses were performed using SPSS 22.0 statistical software (IBM Corp., Armonk, NY, USA).

\section{Results}

The median ages in the pregnant and non-pregnant groups were 28 and 26 years, respectively. The mean WBC counts in the pregnant and non-pregnant groups 
were $14.07 \pm 4.5$ and $13.43 \pm 4.5$, and the median Creactive protein levels were 16.2 [55.03] and 7.64 [41.69] $\mathrm{mg} / \mathrm{dl}$, respectively. The left shift in neutrophils was significantly higher in the pregnant group than in the nonpregnant group; $47(59.5 \%)$ vs. 23 (29.1\%), respectively $(p<0.001)$. The median total bilirubin level was also significantly higher in the non-pregnant group than in the pregnant group; $0.59[0.75]$ vs. $0.47[0.33] \mathrm{mg} / \mathrm{dl}$, respectively $(p<0.001$; Table 1$)$.

Based on the pathology results, 65 pregnant patients $(82.3 \%)$ had appendicitis and $14(17.7 \%)$ did not. In the non-pregnant group, 66 patients $(83.5 \%)$ had appendicitis and $13(16.5 \%)$ did not. There was a significant difference between the groups in terms of severity of pain; most individuals in the non-pregnant group $(54 ; 68.4 \%)$ reported moderate pain, whereas most in the pregnant group $(57 ; 72.2 \%)$ reported a high degree of pain $(p<$ 0.001). Findings in both groups were similar in terms of nausea, vomiting, and anorexia. Pregnant patients typically visited the hospital less than $24 \mathrm{~h}$ from the onset of symptoms. Based on direct examination of pregnant patients, abdominal guarding and rebound tenderness were significantly more common than in non-pregnant patients (Table 2).

We compared the efficacy of scoring systems for both groups. The Tzanakis system was the most efficacious among the scoring systems used in non-pregnant women. The positive predictive value (PPV) of the Tzanakis system was $90.6 \%$, whereas the negative predictive value (NPV) was $46.7 \%$. The sensitivity associated with the Tzanakis score was $87.8 \%$ and the specificity was $53.8 \%$. Based on the area under the curve (AUC) analysis of predictive power, the Tzanakis score had the highest power in the non-pregnant group, followed by the AIR and Alvarado scores (Table 3) (Fig. 1).

RIPASA performed the best among the scoring systems used in pregnant patients. The PPV of this scoring method was $94.40 \%$, its NPV was $44 \%$, and its sensitivity and specificity were $78.46 \%$ and $78.57 \%$, respectively. The AIR and Tzanakis systems were the second- and third-most efficacious, respectively. The PPV of the AIR score was $92.9 \%$, its sensitivity was $80 \%$, and its specificity was $71.4 \%$. The PPV of the Tzanakis score was $97.1 \%$, its sensitivity was $52.3 \%$, and its specificity was 92.8\% (Table 4) (Fig. 2).

\section{Discussion}

Appendicitis is generally diagnosed based on clinical and laboratory findings, including the results of imaging analysis. However, the presence of numerous gynecological pathologies in female patients makes it challenging to diagnose acute appendicitis, particularly in pregnant patients [26]. For example, symptoms such as nausea and vomiting are common during both pregnancy and appendicitis, and laboratory findings also tend to be similar.

Radiological examination has high diagnostic value for acute appendicitis [27]. However, the main disadvantages of computed tomography are its teratogenic effect and high cost $[28,29]$. The presence of positive abdominal ultrasonography (USG) findings in pregnant women with suspected appendicitis is sufficient to confirm the condition. In cases where appendicitis cannot be diagnosed using USG, magnetic resonance imaging provides high diagnostic accuracy in pregnant patients [30-32]. When using new scoring systems that combine clinical and imaging features, $95 \%$ of patients with uncomplicated appendicitis can be diagnosed correctly [33].

Delays in diagnosis and treatment of appendicitis may result in more complicated illness and increased rates of preterm labor, perinatal morbidity, mortality, and fetal loss [6-10]. The use of scoring systems helps to support imaging methods [34, 35]. CSS may be used in acute appendicitis to facilitate early diagnosis of the disease and prevent morbidity, and the Alvarado scoring system is one of the most commonly used systems for this situation [27]. Although the Alvarado system may be used in pregnant patients, its use has been extensively validated mainly in non-pregnant patients [36].

Table 1 Distribution of features related to pregnant and non-pregnant women

\begin{tabular}{lllll}
\hline Variable & Pregnant $(\boldsymbol{n}=79)$ & Non-pregnant $(\boldsymbol{n}=79)$ & $\boldsymbol{p}$ value & Effect size \\
\hline Neutrophil & $10.6[5.6]$ & $10[5.7]$ & 0.559 & -0.046 \\
MPV & $7.96 \pm 1.49$ & $8.74 \pm 1.48$ & 0.001 & -0.524 \\
Total bilirubin & $0.47[0.33]$ & $0.59[0.75]$ & $<0.001$ & -0.324 \\
Age & $28[6]$ & $26[10]$ & 0.236 & -0.094 \\
CRP & $16.2[55.03]$ & $7.64[41.69]$ & 0.28 & -0.175 \\
WBC & $14.07 \pm 4.5$ & $13.43 \pm 4.5$ & 0.376 & 0.141 \\
PMN ratio & $81.8[12.2]$ & $78.6[11.8]$ & 0.078 & -0.140 \\
\hline
\end{tabular}

MPV mean platelet volume, CRP C-reactive protein, WBC white blood count, $P M N$ polymorphonuclear leukocyte 
Table 2 Distribution of features related to pregnant and non-pregnant women

\begin{tabular}{|c|c|c|c|c|}
\hline Variable & Pregnant & Non-pregnant & $p$ value & Effect size* \\
\hline \multicolumn{5}{|l|}{ Pathology } \\
\hline Appendicitis & $65(82.3 \%)$ & $66(83.5 \%)$ & 1 & -0.17 \\
\hline Non-appendicitis & $14(17.7 \%)$ & $13(16.5 \%)$ & & \\
\hline \multicolumn{5}{|l|}{ USG appendicitis } \\
\hline Positive & $57(72.2 \%)$ & $38(48.1 \%)$ & 0.002 & 0.246 \\
\hline Negative & $22(27.8 \%)$ & $41(51.9 \%)$ & & \\
\hline \multicolumn{5}{|l|}{ Pain severity } \\
\hline Mild & $1(1.3 \%)$ & $17(21.5 \%)$ & $<0.001$ & 0.691 \\
\hline Moderate & $21(26.6 \%)$ & $54(68.4 \%)$ & & \\
\hline High & $57(72.2 \%)$ & $5(6.3 \%)$ & & \\
\hline Severe & $0(0 \%)$ & $3(3.8 \%)$ & & \\
\hline \multicolumn{5}{|c|}{ Pain outside the right lower quadrant } \\
\hline Positive & $5(6.3 \%)$ & $11(13.9 \%)$ & 0.186 & -0.126 \\
\hline Negative & $74(93.7 \%)$ & $68(86.1 \%)$ & & \\
\hline \multicolumn{5}{|c|}{ Increased pain in follow-up } \\
\hline Positive & $25(31.6 \%)$ & $35(44.3 \%)$ & 0.101 & -0.13 \\
\hline Negative & $54(68.4 \%)$ & $44(55.7 \%)$ & & \\
\hline \multicolumn{5}{|c|}{ The spread of pain from the umbilicus } \\
\hline Positive & $26(32.9 \%)$ & $48(60.8 \%)$ & $<0.001$ & -0.279 \\
\hline Negative & $53(67.1 \%)$ & $31(39.2 \%)$ & & \\
\hline \multicolumn{5}{|l|}{ Vomiting } \\
\hline Positive & $28(35.4 \%)$ & $11(13.9 \%)$ & 0.003 & 0.25 \\
\hline Negative & $51(64.6 \%)$ & $68(86.1 \%)$ & & \\
\hline \multicolumn{5}{|l|}{ Anorexia } \\
\hline Positive & $31(39.2 \%)$ & $48(60.8 \%)$ & 0.007 & -0.215 \\
\hline Negative & $48(60.8 \%)$ & $31(39.2 \%)$ & & \\
\hline \multicolumn{5}{|c|}{ Duration of symptoms } \\
\hline$<24 \mathrm{~h}$ & $60(75.9 \%)$ & $23(29.1 \%)$ & $<0.001$ & 0.471 \\
\hline $24-48 h$ & $12(15.2 \%)$ & $40(50.6 \%)$ & & \\
\hline$>48 \mathrm{~h}$ & $7(8.9 \%)$ & $14(20.3 \%)$ & & \\
\hline \multicolumn{5}{|c|}{ Right lower quadrant pain with cough } \\
\hline Positive & $36(45.6 \%)$ & $48(60.8 \%)$ & 0.560 & -0.152 \\
\hline Negative & $43(54.4 \%)$ & $31(39.2 \%)$ & & \\
\hline \multicolumn{5}{|l|}{ Bowel sounds } \\
\hline Increased/metallic & $1(1.3 \%)$ & $4(5.1 \%)$ & $<0.001$ & 0.537 \\
\hline Normal & $39(49.4 \%)$ & $73(94.2 \%)$ & & \\
\hline Absent & $39(49.4 \%)$ & $2(2.5 \%)$ & & \\
\hline \multicolumn{5}{|l|}{ Defense } \\
\hline Absent & $0(0 \%)$ & $24(30.4 \%)$ & $<0.001$ & 0.693 \\
\hline Mild & $1(1.3 \%)$ & $10(12.7 \%)$ & & \\
\hline Moderate & $26(32.9 \%)$ & $41(51.9 \%)$ & & \\
\hline Severe & $52(65.8 \%)$ & $4(5.1 \%)$ & & \\
\hline \multicolumn{5}{|c|}{ Right lower quadrant sensitivity } \\
\hline Positive & 79 (100\%) & $78(98.7 \%)$ & 1 & 0.08 \\
\hline
\end{tabular}


Table 2 Distribution of features related to pregnant and non-pregnant women (Continued)

\begin{tabular}{|c|c|c|c|c|}
\hline Variable & Pregnant & Non-pregnant & $p$ value & Effect size ${ }^{*}$ \\
\hline Negative & $0(0 \%)$ & $1(1.3 \%)$ & & \\
\hline \multicolumn{5}{|l|}{ Rebound } \\
\hline Positive & 75 (94.8\%) & $58(73.4 \%)$ & $<0.001$ & 0.295 \\
\hline Negative & $4(5.1 \%)$ & $21(26.6 \%)$ & & \\
\hline \multicolumn{5}{|c|}{ Rovsing's sign } \\
\hline Positive & 37 (46.8\%) & $16(20.3 \%)$ & 0.001 & 0.282 \\
\hline Negative & 42 (53.2\%) & $63(79.7 \%)$ & & \\
\hline \multicolumn{5}{|l|}{ Pyrexia } \\
\hline Positive & $16(20.3 \%)$ & $12(15.2 \%)$ & 0.532 & 0.066 \\
\hline Negative & $63(79.7 \%)$ & $67(84.8 \%)$ & & \\
\hline \multicolumn{5}{|c|}{ Left shift in neutrophils } \\
\hline Positive & $47(59.5 \%)$ & $23(29.1 \%)$ & $<0.001$ & 0.306 \\
\hline Negative & $32(40.5 \%)$ & $56(70.9 \%)$ & & \\
\hline \multicolumn{5}{|c|}{ Negative urinalysis } \\
\hline Positive & $79(100 \%)$ & $44(55.7 \%)$ & $<0.001$ & 0.533 \\
\hline Negative & $0(0 \%)$ & $35(44.3 \%)$ & & \\
\hline \multicolumn{5}{|c|}{ Follow-up time } \\
\hline 1 day & 69 (87.3\%) & $53(67.1 \%)$ & 0.003 & 0.247 \\
\hline 2 days & $9(11.4 \%)$ & $25(31.6 \%)$ & & \\
\hline 3 days & $1(1.3 \%)$ & $1(1.3 \%)$ & & \\
\hline
\end{tabular}

The data are shown in number and percentage format

*Phi or Cramer $V$ coefficient is given as the effect size measure

CSS aim to diagnose appendicitis by assessing signs, symptoms, and laboratory results. Systems use different variables. For example, the Tzanakis system includes USG results as a factor, the Lintula and Fenyo-Lindberg systems include gender, and the RIPASA and Ohmann systems include urinary symptoms. In our study, we assessed nine different scoring systems that are commonly used worldwide to diagnose appendicitis and compared their performance in pregnant and non-pregnant patients.
The presence of nausea, vomiting, and physiological leukocytosis during pregnancy makes it challenging to diagnose appendicitis, as does the fact that the position of the appendix changes during the gestation period [26]. In addition to our traditional knowledge, while rare publications are stating that the position of the appendix does not vary during pregnancy, publications with high volume are inevitably required to clarify this circumstance $[37,38]$. This may explain why the negative

Table 3 Distribution of appendicitis diagnostic performance criteria of scoring systems used in non-pregnant women

\begin{tabular}{|c|c|c|c|c|c|c|c|}
\hline Variable(s) & AUC & $p$ & PPV & NPV & Sensitivity & Specificity & Cutoff \\
\hline Karaman & 0.752 & 0.004 & 90.90 & 43.70 & 86.36 & 53.85 & 0.00 \\
\hline Alvarado & 0.772 & 0.002 & 91.90 & 47.10 & 86.36 & 61.54 & 4.00 \\
\hline RIPASA & 0.757 & 0.004 & 90.60 & 46.70 & 87.80 & 53.85 & 6.00 \\
\hline Tzanakis & 0.794 & 0.001 & 90.60 & 46.70 & 87.80 & 53.85 & 6.00 \\
\hline AIR & 0.787 & 0.001 & 94.20 & 37.00 & 74.24 & 76.92 & 4.00 \\
\hline Eskelinen & 0.735 & 0.008 & 92.20 & 53.30 & 89.39 & 61.54 & 56.73 \\
\hline Ohmann & 0.734 & 0.008 & 91.80 & 44.40 & 84.85 & 61.54 & 10.50 \\
\hline Lintula & 0.675 & 0.047 & 89.60 & 50.00 & 90.91 & 46.15 & 8.00 \\
\hline Fenyo-Lindberg & 0.705 & 0.020 & 91.70 & 42.10 & 83.33 & 61.54 & -33.00 \\
\hline
\end{tabular}




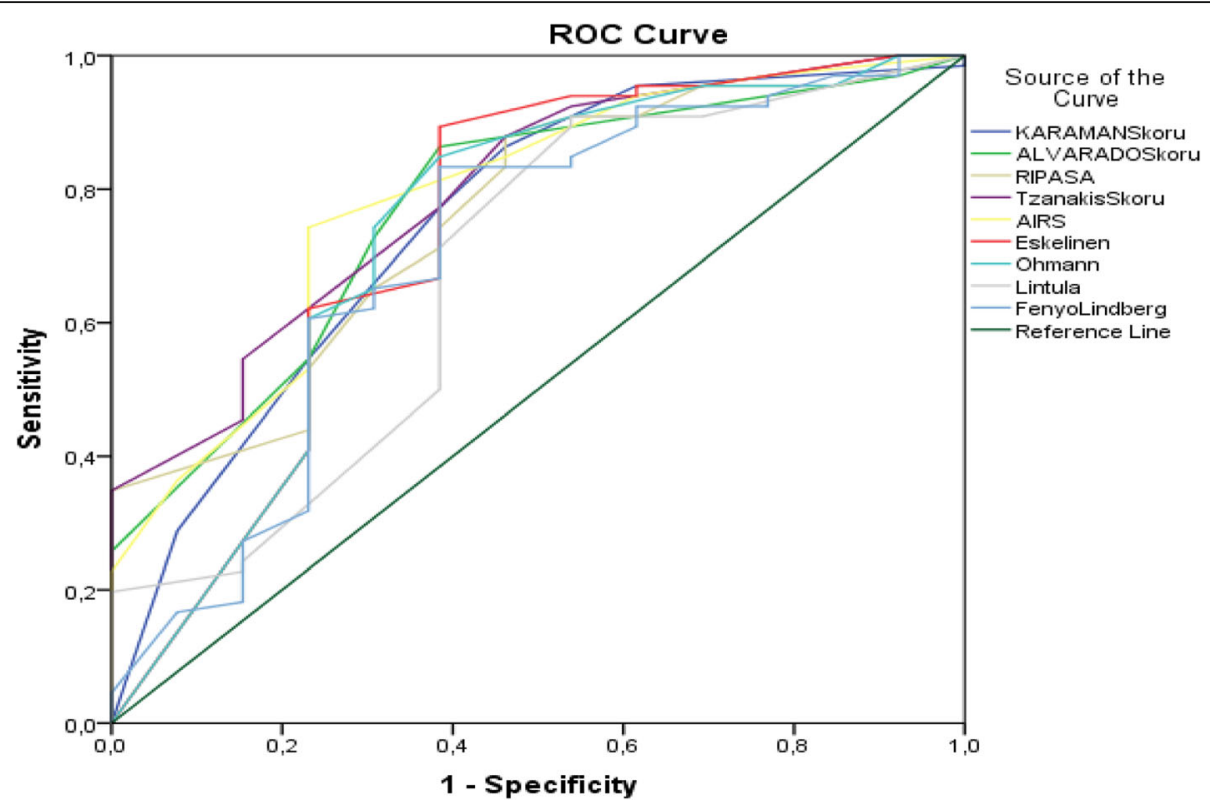

Fig. 1 ROC curves for diagnostic performance of appendicitis scoring systems for non-pregnant women

appendectomy rate is approximately $35 \%$ in pregnant patients [39]. Currently, there is no scoring system that specifically evaluates appendicitis during pregnancy. Therefore, we evaluated the efficacy of existing scoring systems in pregnant patients. Based on AUC analysis, the scoring systems with the highest predictive power for non-pregnant women were the Tzanakis, AIR, and Alvarado systems, in that order. The Lintula and FenyoLindberg scoring systems produced the lowest AUC values among the nine scoring systems. These results suggest that including USG findings (e.g., as in the Tzanakis system) is valuable for the diagnosis of appendicitis in non-pregnant patients.

For pregnant women, the RIPASA score had the highest predictive value, followed by the AIR and Tzanakis scores. Scoring systems that were heavily based on signs and detailed laboratory findings had greater predictive power in the pregnant group. Although we determined that the RIPASA system performed best in pregnant patients, its sensitivity and specificity were below $80 \%$. Based on our findings, we intend to conduct further CSS research focused on the gestation period.

The potential limitations of our study included its retrospective design, the small number of cases, and the retrospective control group, which may not have been representative of the main group.

In summary, systems that include variables such as changes in the neutrophil count, negative urinary findings, Rovsing's sign, rebound, severe abdominal defense, absence of bowel sounds, short symptom duration, and

Table 4 Distribution of appendicitis diagnostic performance criteria of scoring systems used in pregnant women

\begin{tabular}{|c|c|c|c|c|c|c|c|}
\hline Variable(s) & AUC & $p$ & PPV & NPV & Sensitivity & Specificity & Cutoff \\
\hline Karaman & 0.638 & 0.106 & 87.20 & 25.00 & 63.08 & 57.14 & 3.00 \\
\hline Alvarado & 0.724 & 0.009 & 92.70 & 28.90 & 58.46 & 78.57 & 6.00 \\
\hline RIPASA & 0.806 & 0.000 & 94.40 & 44.00 & 78.46 & 78.57 & 8.50 \\
\hline Tzanakis & 0.786 & 0.001 & 97.10 & 29.50 & 52.31 & 92.86 & 13.00 \\
\hline AIR & 0.795 & 0.001 & 92.90 & 43.50 & 80.00 & 71.43 & 6.00 \\
\hline Eskelinen & 0.688 & 0.028 & 89.80 & 40.00 & 81.54 & 57.14 & 65.47 \\
\hline Ohmann & 0.613 & 0.186 & 88.70 & 41.20 & 84.62 & 50.00 & 12.50 \\
\hline Lintula & 0.723 & 0.009 & 91.80 & 33.30 & 69.23 & 71.43 & 19.00 \\
\hline Fenyo-Lindberg & 0.498 & 0.980 & 25.00 & 14.70 & 1.54 & 78.57 & -36.00 \\
\hline
\end{tabular}




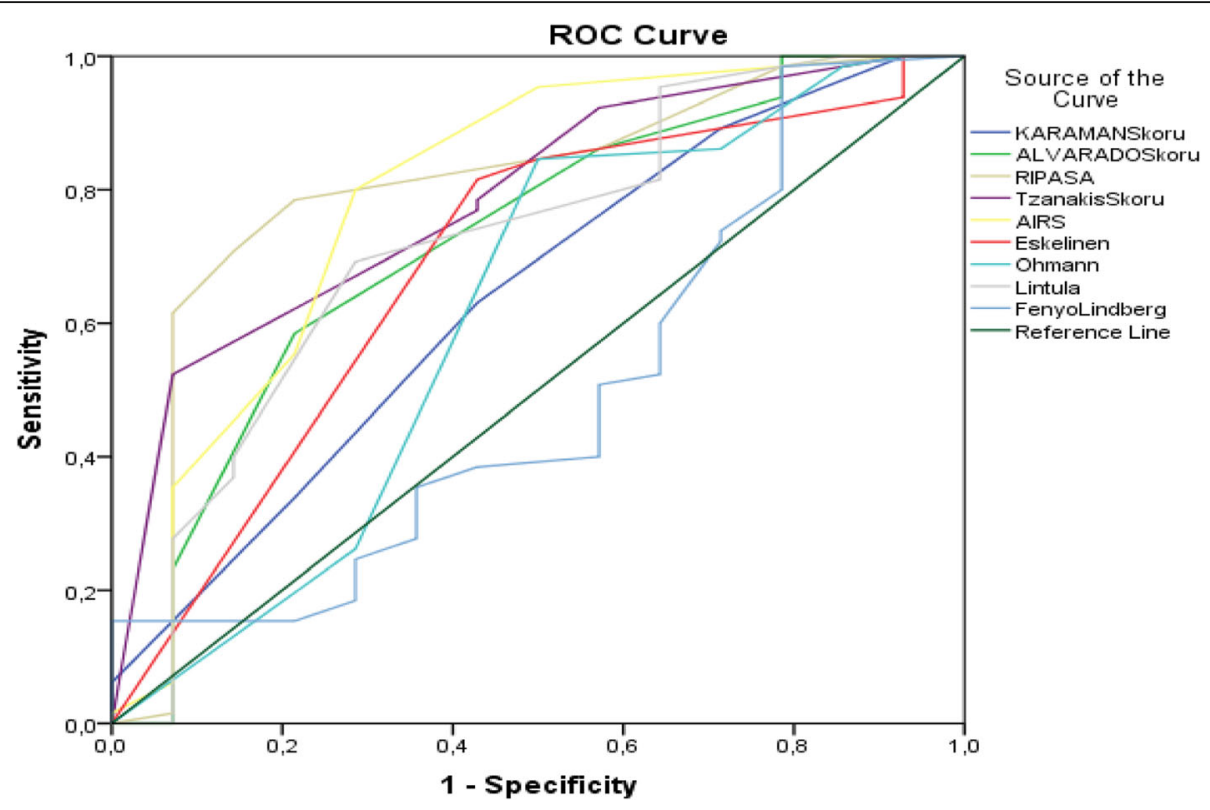

Fig. 2 ROC curves for diagnostic performance of appendicitis scoring systems in pregnant women

severe abdominal pain perform well in pregnant patients (Table 2). Systems that score gender and pain displacement are less efficacious for pregnant patients. Notably, with the progression of pregnancy, the gravid uterus may affect pain migration.

\section{Conclusion}

Among the CSS evaluated, the RIPASA system was found to be the most suitable for pregnant patients, and this system may also help guide the use of imaging methods for pregnant patients in the clinic. Scoring systems tailored for acute appendicitis during the gestation period will improve treatment outcomes for both the mother and fetus.

\section{Abbreviations}

ROC: Receiver operating characteristics; PPV: Positive predictive value; NPV: Negative predictive value; WBC: White blood count; VAS: Visual analog scale; AUC: Area under the curve; CT: Computed tomography; USG: Abdominal ultrasonography; MRI: Magnetic resonance imaging; CSS: Clinical scoring systems; NOM: Non-operative management

\section{Acknowledgements}

None

\section{Authors' contributions}

BM: design, data collection, data analysis + interpretation, writing and revision. YA: Data collection, data interpretation, and revision. MY: Data analysis, interpretation, and writing. FA: Interpretation and revision. EG: study design, data interpretation, and revision. EA: study design, writing/revision. UE: data interpretation, revision. NF: interpretation and revision. The authors read and approved the final manuscript.

\section{Funding}

None

\section{Availability of data and materials}

There is no additional data available to share with the readers. The datasets used and/or analyzed during the current study are available from the corresponding author on reasonable request.

Ethics approval and consent to participate

Sakarya University Ethics Committee has approved this research project.

\section{Consent for publication}

All patients or their caregivers signed a consent form giving permission to use their anonymous data for research.

\section{Competing interests}

The authors have no conflicts of interest. The authors are responsible for the content of the paper.

\section{Author details}

'Department of General Surgery, Sakarya University Educating and Research Hospital, Sakarya, Turkey. ${ }^{2}$ Faculty of Medicine, Department of General

Surgery, Sakarya University, Sakarya, Turkey. ${ }^{3}$ Faculty of Medicine, Department of Biostatistics, Sakarya University, Sakarya, Turkey.

Received: 26 March 2020 Accepted: 21 April 2020

Published online: 18 May 2020

\section{References}

1. Babaknia A, Parsa H, Woodruff JD. Appendicitis during pregnancy. Obstet Gynecol. 1977:50:40-4.

2. Flum DR, Morris A, Koepsell T, Dellinger EP. Has misdiagnosis of appendicitis decreased over time? A population-based analysis. J Am Med Assoc. 2001; 286:1748-53.

3. De Franca Neto AH, Do Amorim MMR, Nóbrega BMSV. Acute appendicitis in pregnancy: literature review. Vol. 61, Revista da Associacao Medica Brasileira. 2015. p. 170-7.

4. Long SS, Long C, Lai H, Macura KJ. Imaging strategies for right lower quadrant pain in pregnancy. American Journal of Roentgenology. 2011;196: 4-12.

5. Lurie S, Rahamim E, Piper I, Golan A, Sadan O. Total and differential leukocyte counts percentiles in normal pregnancy. Eur J Obstet Gynecol Reprod Biol. 2008;136:16-9. 
6. Corneille MG, Gallup TM, Bening T, Wolf SE, Brougher C, Myers JG, et al. The use of laparoscopic surgery in pregnancy: evaluation of safety and efficacy. Am J Surg. 2010;200:363-7.

7. Yoo KC, Park JH, Pak KH, Kim KY, Lee BH, Kim BC, et al. Could laparoscopic appendectomy in pregnant women affect obstetric outcomes? A multicenter study. Int J Colorectal Dis. 2016;1475:81.

8. Fallon WF, Newman JS, Fallon GL, Malangoni MA. The surgical management of intra-abdominal inflammatory conditions during pregnancy. Surg Clin North Am. 1995;75:15-31.

9. Palanivelu C, Rangarajan M, Senthilkumaran S, Parthasarathi R. Safety and efficacy of laparoscopic surgery in pregnancy: experience of a single institution. J Laparoendosc Adv Surg Tech A. 2007;17:186-90.

10. Al-Qudah MS, Amr M, Sroujieh A, Issa A. Appendectomy in pregnancy: the experience of a university hospital. J Obstet Gynaecol. 1999;19:362-4.

11. Andersson RE. The natural history and traditional management of appendicitis revisited: spontaneous resolution and predominance of prehospital perforations imply that a correct diagnosis is more important than an early diagnosis. World Journal of Surgery. 2007. World J Surg. 2007; 31:86-92.

12. van Dijk ST, van Dijk AH, Dijkgraaf MG, Boermeester MA. Meta-analysis of inhospital delay before surgery as a risk factor for complications in patients with acute appendicitis. Br J Surg. 2018;105:933-45.

13. Podda M, Gerardi C, Cillara N, Fearnhead N, Gomes CA, Birindelli A, et al. Antibiotic treatment and appendectomy for uncomplicated acute appendicitis in adults and children: a systematic review and meta-analysis. Ann Surg. 2019;270:1028-40

14. Cheng HT, Wang YC, Lo HC, Su LT, Soh KS, Tzeng CW, et al. Laparoscopic appendectomy versus open appendectomy in pregnancy: a populationbased analysis of maternal outcome. Surg Endosc. 2015;29:1394-9.

15. Guttman R, Goldman RD, Koren G. Appendicitis during pregnancy. Can Fam Physician. 2004;50:355-7.

16. Alvarado A. A practical score for the early diagnosis of acute appendicitis. Ann Emerg Med. 1986;15:567-4.

17. Tzanakis NE, Efstathiou SP, Danulidis K, Rallis GE, Tsioulos DI, Chatzivasiliou A, et al. A new approach to accurate diagnosis of acute appendicitis. World J Surg. 2005;29:1151-6.

18. Butt MQ, Chatha SS, Ghumman AQ, Farooq M. RIPASA score: a new diagnostic score for diagnosis of acute appendicitis. J Coll Physicians Surg Pak. 2014;24:894-7.

19. Von-Mühlen B, Franzon O, Beduschi MG, Kruel N, Lupselo D. AlR score assessment for acute appendicitis. Arq Bras Cir Dig. 2015;28:171-3.

20. Sitter H, Hoffmann S, Hassan I, Zielke A. Diagnostic score in appendicitis: validation of a diagnostic score (Eskelinen score) in patients in whom acute appendicitis is suspected. Langenbeck's Arch Surg. 2004;389:213-8.

21. Ohmann C, Yang Q, Franke C. Diagnostic scores for acute appendicitis. Abdominal Pain Study Group. Eur J Surg. 1995;161:273-81.

22. Lintula H, Kokki H, Pulkkinen J, Kettunen R, Gröhn O, Eskelinen M. Diagnostic score in acute appendicitis. Validation of a diagnostic score (Lintula score) for adults with suspected appendicitis. Langenbecks Arch Surg. 2010;395:495-500.

23. Karaman K, Ercan M, Demir H, Yalkın Ö, Uzunoğlu Y, Gündoğdu K, et al. The Karaman score: a new diagnostic score for acute appendicitis. Ulus Travma ve Acil Cerrahi Derg. 2018;24:545-51.

24. Fenyö $G$, Lindberg $G$, Blind P, Enochsson L, Öberg Å. Diagnostic decision support in suspected acute appendicitis: validation of a simplified scoring system. Eur J Surg. 1997;163:831-8.

25. Hayes MH. Patterson DG. Psychol Bull: Experimental development of the graphic rating method; 1921

26. Zachariah SK, Fenn M, Jacob K, Arthungal SA, Zachariah SA. Management of acute abdomen in pregnancy: current perspectives. Int J Womens Health. 2019;11:119-34

27. Sartelli M, Baiocchi GL, Di Saverio S, Ferrara F, Labricciosa FM, Ansaloni L, et al. Prospective Observational Study on acute Appendicitis Worldwide (POSAW). World J Emerg Surg. 2018;13:19.

28. Brenner DJ, Doll R, Goodhead DT, Hall EJ, Land CE, Little JB, et al. Cancer risks attributable to low doses of ionizing radiation: assessing what we really know. Proc Natl Acad Sci U S A. 2003;100:13761-6.

29. Guidelines for diagnostic imaging during pregnancy and lactation. Obstet Gynecol. 2017;130:e210-e216.

30. Theilen LH, Mellnick VM, Longman RE, Tuuli MG, Odibo AO, MacOnes GA, et al. Utility of magnetic resonance imaging for suspected appendicitis in pregnant women. Am J Obstet Gynecol. 2015;212:345.e1-345.e3456.
31. Spalluto LB, Woodfield CA, Debenedectis CM, Lazarus E. MR imaging evaluation of abdominal pain during pregnancy: appendicitis and other nonobstetric causes. Radiographics. 2012;32:317-34.

32. Freeland M, King E, Safcsak K, Durham R. Diagnosis of appendicitis in pregnancy. Am J Surg. 2009;198:753-8.

33. Atema JJ, Van Rossem CC, Leeuwenburgh MM, Stoker J, Boermeester MA. Scoring system to distinguish uncomplicated from complicated acute appendicitis. Br J Surg. 2015;102:979-90.

34. Tan WJ, Pek W, Kabir T, et al. Alvarado score: a guide to computed tomography utilization in appendicitis. ANZ J Surg. 2013;83:748-52.

35. Jones RP, Brooke Jeffrey R, Shah BR, Desser TS, Rosenberg J, Olcott EW. The Alvarado score as a method for reducing the number of $C T$ studies when appendiceal ultrasound fails to visualize the appendix in adults. Am J Roentgenol. 2015;204:519-26.

36. Augustin G, Majerovic M. Non-obstetrical acute abdomen during pregnancy. Eur J Obstet Gynecol Reprod Biol. 2007;131:4-12.

37. Ishaq A, Khan MJH, Pishori T, Soomro R, Khan S. Location of appendix in pregnancy: does it change? Clin Exp Gastroenterol. 2018;11:281-7.

38. Hodjati $\mathrm{H}$, Kazerooni T. Location of the appendix in the gravid patient: a reevaluation of the established concept. Int J Gynecol Obstet. 2003;81:245-7.

39. McGory ML, Zingmond DS, Tillou A, Hiatt JR, Ko CY, Cryer HM. Negative appendectomy in pregnant women is associated with a substantial risk of fetal loss. J Am Coll Surg. 2007;205:534-40.

\section{Publisher's Note}

Springer Nature remains neutral with regard to jurisdictional claims in published maps and institutional affiliations.
Ready to submit your research? Choose BMC and benefit from:

- fast, convenient online submission

- thorough peer review by experienced researchers in your field

- rapid publication on acceptance

- support for research data, including large and complex data types

- gold Open Access which fosters wider collaboration and increased citations

- maximum visibility for your research: over $100 \mathrm{M}$ website views per year

At BMC, research is always in progress.

Learn more biomedcentral.com/submissions 